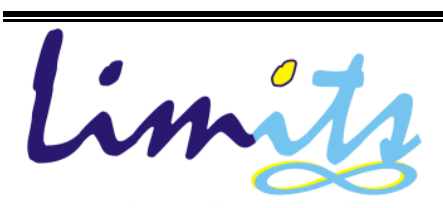

J. Math. and Its Appl.

E-ISSN: 2579-8936

P-ISSN: $1829-605 \mathrm{X}$

Vol. 15, No. 2, Nopember 2018, 97-112

\title{
Analisis Model Matematika Orde Fraksional Penyebaran Worm Berbasis Wi-Fi Pada Smartphone
}

\author{
Mohammad Imam Utoyo ${ }^{1 *}$, Er Ayu Nurafifah ${ }^{2}$, Miswanto ${ }^{3}$ \\ ${ }^{1,2,3}$ Departemen Matematika Universitas Airlangga Surabaya Indonesia \\ ${ }^{1}$ m.i.utoyo@fst.unair.ac.id \\ 2er.ayu.nurafifah-2014@fst.unair.ac.id, \\ _3 miswanto@fst.unair.ac.id
}

\begin{abstract}
Abstrak
Worm merupakan suatu program atau software (perangkat lunak) yang memiliki kemampuan mereplikasi diri dan dapat menyebabkan kerusakan pada jaringan komputer. Pada umumnya worm menginfeksi jaringan komputer, namun seiring dengan perkembangan teknologi menyebabkan munculnya worm jenis baru yaitu worm berbasis Wi-Fi (Wireless Fidelity) yang dapat menginfeksi smartphone. Salah satu upaya penanggulangan worm adalah dengan menambahkan sebuah node baru pada jaringan Wi-Fi yaitu node karantina untuk meminimalisir penyebaran worm pada smartphone. Model matematika penyebaran worm berbasis Wi-Fi pada smartphone dapat digunakan untuk mengetahui dinamika penyebaran worm. Melalui dinamika penyebaran worm, dapat dipelajari faktor penghambat infeksi worm. Pada penelitian ini dilakukan analisis kestabilan titik setimbang model matematika orde fraksional penyebaran worm berbasis Wi-Fi pada smartphone dengan orde turunan fraksional $\alpha \in(0,1]$. Berdasarkan analisis model, diperoleh dua titik setimbang yaitu titik setimbang bebas worm $P_{0}$ dan titik setimbang endemik $P_{1}$. Titik setimbang bebas worm stabil asimtotis lokal jika basic reproduction number $R_{0}<1$, sedangkan titik setimbang endemik stabil asimtotis lokal jika basic reproduction number $R_{0}>1$. Kemudian dilakukan analisis sensitivitas dan simulasi numerik dengan variasi nilai orde fraksional $\alpha$ untuk mengetahui dinamika penyebaran worm berbasis $\mathrm{Wi}$ - $\mathrm{Fi}$ pada smartphone. Berdasarkan hasil simulasi numerik diperoleh hasil bahwa penambahan node karantina pada jaringan $\mathrm{Wi}$ - $\mathrm{Fi}$ dapat menurunkan populasi node terinfeksi dan meningkatkan populasi node yang pulih.
\end{abstract}

Kata Kunci: Worm Berbasis Wi-Fi, Model Matematika Orde Fraksional, Titik Setimbang, Kestabilan

\begin{abstract}
Worm is a software that has the ability to replicate itself and it can cause damage on a computer network. Generally, the worm infects computer network, but along with development of technology causing the emergence of new worm that is a Wi-Fi (Wireless Fidelity) based worm that can infect smartphone. One of the ways to prevent smarphone from worm is by adding a new node to the Wi-Fi network, that is quarantine the node to minimize the spread of worm on smartphone. Mathematical models of Wi-Fi based worm deployment can be used to determine the dynamics of the spread of Wi-Fi based worm in smartphone. Inhibiting factor of worm infection can be studied through the dynamics of the spread of worm. In this paper, we present a fractional model of the spread of Wi-Fi based worm in smartphone with the fractional order derivative $\alpha \in(0,1]$. After that, the stability of the equilibriums of fractional model can be determined. Based on the model analysis, we obtained two equilibriums, namely free-worm equilibrium $P_{0}$ and endemic equilibrium $P_{1}$. The free-worm $P_{0}$ is locally asymptotically stable if basic reproduction number $R_{0}<1$, while the equilibrium $P_{1}$ is locally asymptotically stable if basic reproduction number $R_{0}>1$. We also analyze the sensitivity of parameters to determine the most
\end{abstract}


influence parameter to the spread of Wi-Fi based worm. Furthermore, we perform numerical simulations with variations of $\alpha$ to illustrate the dynamical of the spread of Wi-Fi based worm in smartphone. Based on the numerical simulations, we obtained that addition of quarantine node in Wi-Fi network can decrease the population of infected nodes and increase the population of recovered nodes.

Keywords: Wi-Fi Based Worm, Fractional Mathematical Model, Equilibriums, Stability..

\section{Pendahuluan}

Pada saat ini, teknologi mengalami perkembangan yang cukup pesat. Sebagian besar masyarakat menjadikan teknologi sebagai kebutuhan mendasar dalam aspek kehidupan mereka. Wi-Fi (Wireless Fidelity) dan smartphone merupakan salah satu perkembangan teknologi pada bidang komunikasi dan informasi. Wi-Fi (Wireless Fidelity) dikenal sebagai sentra hotspot yang dapat memudahkan manusia untuk berkomunikasi atau bertukar informasi dengan kemampuan yang sangat cepat. Lebih dari 18 juta orang di seluruh dunia telah memanfaatkan teknologi Wi-Fi (Wireless Fidelity) dan setiap hari jumlahnya semakin bertambah [1]. Dalam beberapa tahun terakhir, Wi-Fi (Wireless Fidelity) dan smartphone telah banyak memfasilitasi masyarakat untuk menjalani kehidupan sehari-harinya. Berdasarkan data dari KOMINFO, lembaga riset digital marketing Emarketer memperkirakan pada tahun 2018 jumlah pengguna aktif smartphone di Indonesia mencapai lebih dari 100 juta orang [2].

Semakin banyak pengguna smartphone dan Wi-Fi yang terhubung ke internet, akan menyebabkan worm jenis baru dapat berkembang biak, salah satunya yaitu worm berbasis Wi-Fi (Wireless Fidelity). Worm tersebut dikenal dengan sebutan Chameleon. Chameleon merupakan jenis worm berbasis Wi-Fi yang dapat menyebar melalui acces point pada satu jaringan Wi-Fi ke jaringan Wi-Fi yang lain. Chameleon bekerja tanpa mengganggu kinerja acces point. Namun, worm tersebut dapat mengumpulkan data-data penting pada saat melewati jaringan $W i-F \mathrm{i}$, seperti password, kartu kredit, atau akun bank. Chameleon bereplikasi tanpa bantuan manusia dengan mencoba memecahkan kata sandi setiap router Wi-Fi baru yang ditemuinya. Chameleon dapat diibaratkan seperti organisme yang menular secara biologis, melompat di antara jaringan $\mathrm{Wi}-\mathrm{Fi}$ yang saling tumpang tindih seperti penyakit di udara yang menyebar di antara manusia (Scharr dalam [3]).

Chameleon tidak dapat terdeteksi oleh antivirus karena antivirus hanya mampu melacak worm pada internet dan worm yang berada di dalam komputer. Chameleon bersembunyi di antara jaringan $W i-F i$ dan menginfeksi jaringan Wi-Fi yang tidak terproteksi password. Chameleon dapat menyerang smartphone yang terhubung ke jaringan Wi-Fi karena mayoritas smartphone tidak memiliki cara yang efektif untuk mencegah serangan worm, sehingga hal 
tersebut menjadikan smartphone rentan terhadap serangan worm. Smartphone yang terganggu oleh worm menyebabkan kerugian yang besar bagi pengguna smartphone seperti kebocoran data, kerusakan sistem dan kerugian finansial [3].

Beberapa peneliti telah mempelajari dinamika penyebaran worm. Pada penelitian sebelumnya, Yuan dkk [4] telah menjelaskan model matematika pada penyebaran worm dengan adanya masa inkubasi. Selain itu, Xiao dkk [3] mengkontruksi model penyebaran worm berbasis Wi-Fi pada smartphone dengan adanya masa karantina. Xiao dkk [3] membagi populasi node menjadi lima subpopulasi yaitu, populasi node yang rentan terhadap worm $(S)$, poulasi node yang terinfeksi worm tetapi belum bisa menyebarkan worm ke node lain $(E)$, populasi node yang terinfeksi worm $(I)$, populasi node yang dikarantina $(Q)$ dan populasi node yang pulih $(R)$.

Dengan menggunakan model matematika dapat diketahui dinamika penyebaran worm berbasis $W i-F i$ pada smartphone dan karenanya dapat dipelajari faktor yang dapat mengurangi penyebaran worm berbasis Wi-Fi pada smartphone. Model penyebaran worm berbasis Wi-Fi pada smartphone telah dikembangkan oleh Xiao dkk [3] dalam bentuk Sistem Persamaan Diferensial Biasa (SPBD) non linear. SPBD non linear tersebut dapat diperumum menjadi Sistem Persamaan Diferensial Orde Fraksional (SPDF) dengan mengubah order turunan pertamanya yaitu $\alpha=1$ menjadi $0<\alpha \leq 1$ sebagaimana telah dilakukan oleh Das dan Gupta [5]. Pada tahun 2016, Angstmann dkk [6] menganalisis dan memodifikasi model matematika SIR yang berbentuk SPDB non linear kedalam bentuk SPDF. Secara alami, SPDF berkaitan dengan faktor histori dari suatu penyebaran penyakit pada sistem biologis. Dengan menggunakan analisis kestabilan pada SPDF diperoleh syarat cukup untuk kestabilan titik setimbang endemik dari model matematika tersebut.

Berdasarkan uraian di atas, pada penelitian ini akan dikembangkan model SPDF dari model SPDB Xiao dkk [3]. Selanjutnya akan ditentukan titik setimbang dan kestabilannya, serta akan dilakukan simulasi numerik dan interpretasinya.

\section{Metode Penelitian}

\subsection{Formulasi Model Matematika}

Model matematika penyebaran worm berbasis Wi-Fi pada smartphone yang ditulis oleh Xiao dkk [3] terdiri dari lima subpopulasi, yaitu populasi node yang rentan pada saat $t(S(t))$, populasi node yang laten pada saat $t(E(t))$, populasi node yang terinfeksi worm pada saat $t$ $(I(t))$, populasi node yang telah terinfeksi worm pada saat $t$ dan dikarantina $(Q(t))$, populasi 
node yang telah pulih pada saat $t(R(t))$. Asumsi yang digunakan untuk mengkonstruksi model adalah sebagai berikut :

1. Semua node rentan terhadap serangan worm.

2. Laju masuknya node baru ke populasi sama dengan laju kerusakan alami node dalam sistem.

Deskripsi parameter dan diagram transmisi pada model disajikan pada Tabel 1 dan Gambar 1 di bawah.

Tabel 1 Deskripsi Parameter

\begin{tabular}{cll}
\hline Parameter & \multicolumn{1}{c}{ Deskripsi } & \multicolumn{1}{c}{ Satuan } \\
\hline $\boldsymbol{\mu}$ & $\begin{array}{l}\text { Laju masuknya node baru ke populasi dan } \\
\text { laju kerusakan alami }\end{array}$ & 1/satuan waktu \\
$\boldsymbol{\beta}$ & $\begin{array}{l}\text { Laju kontak antara node yang rentan } \\
\text { dengan node yang terinfeksi }\end{array}$ & 1/node×satuan \\
& Laju transisi dari node yang dikarantina & 1/satuan waktu \\
$\boldsymbol{\varphi}$ & menjadi node yang pulih & \\
$\boldsymbol{\gamma}$ & Laju transisi dari node yang terinfeksi & 1/satuan waktu \\
& menjadi node yang pulih & \\
$\boldsymbol{\varepsilon}$ & Laju transisi dari node laten menjadi node & 1/satuan waktu \\
& yang pulih & \\
$\boldsymbol{\eta}$ & Laju transisi dari node laten menjadi node & 1/satuan waktu \\
& yang terinfeksi & \\
$\boldsymbol{\xi}$ & Laju transisi dari node yang terinfeksi & 1/satuan waktu \\
& menjadi node yang dikarantina
\end{tabular}

Diagram transmisi yang menggambarkan interaksi lima kompartemen tersebut disajikan pada Gambar 1 berikut:

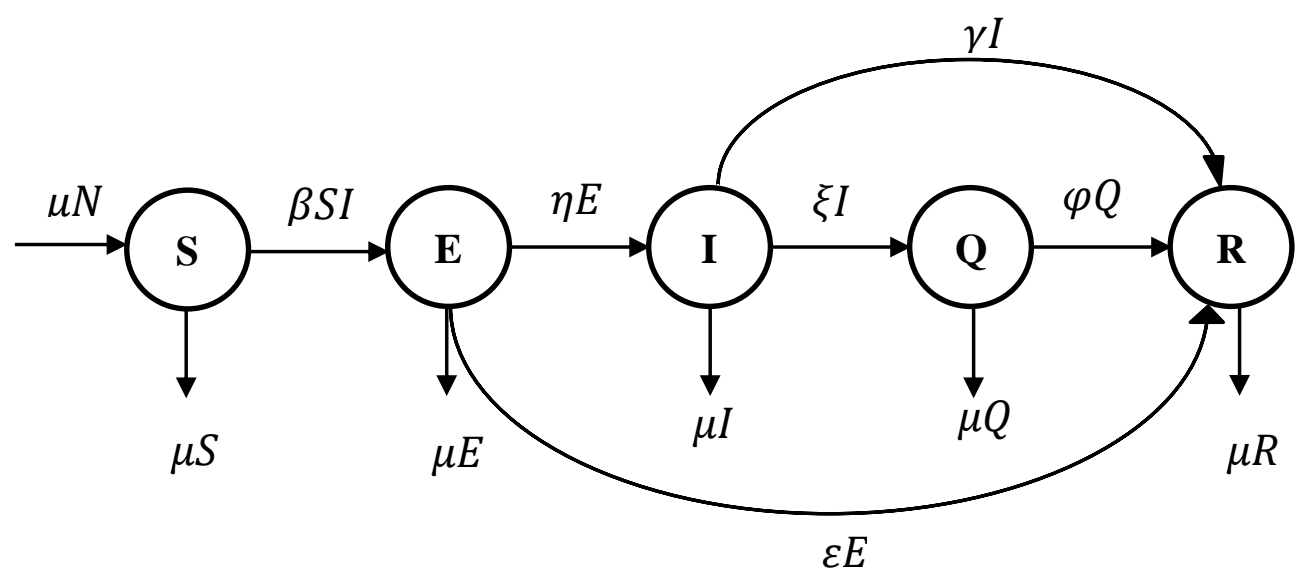


Gambar 1 Diagram Transmisi Model Matematika Penyebaran Worm Berbasis Wi-Fi Pada

\section{Smartphone}

Keterangan :

$\longrightarrow$ : Mengurangi populasi asal dan menambah populasi yang dituju.

Berdasarkan diagram transmisi pada Gambar 1 di atas, Xiao dkk [3] membangun model matematika penyebaran worm berbasis Wi-Fi pada smartphone sebagai berikut:

$$
\begin{aligned}
& \frac{d S(t)}{d t}=-\beta S I+\mu N-\mu S \\
& \frac{d E(t)}{d t}=\beta S I-\eta E-\varepsilon E-\mu E \\
& \frac{d I(t)}{d t}=\eta E-\mu I-\xi I-\gamma I \\
& \frac{d Q(t)}{d t}=\xi I-\varphi Q-\mu Q \\
& \frac{d R(t)}{d t}=\varepsilon E+\gamma I+\varphi Q-\mu R
\end{aligned}
$$

dengan $\mu, \beta, \varphi, \gamma, \varepsilon, \eta, \xi>0, S(t), E(t), I(t), Q(t), R(t) \geq 0$ dan $\frac{d N}{d t}=0$ sehingga $N(t)=$ $S(t)+E(t)+I(t)+Q(t)+R(t)$ konstan.

Persamaan (1a) menyatakan laju perubahan populasi node yang rentan terhadap waktu. Populasi node yang rentan bertambah karena adanya laju masuknya node baru pada populasi dan berkurang karena adanya laju interaksi antara populasi node yang rentan dengan populasi node yang terinfeksi worm. Selain itu, populasi node yang rentan berkurang karena adanya kerusakan alami pada node yang rentan terinfeksi worm. Persamaan (1b) menyatakan laju perubahan populasi node yang laten terhadap waktu. Laju populasi ini bertambah karena adanya interaksi antara populasi node yang rentan dengan populasi node yang telah terinfeksi worm, sedangkan berkurang karena adanya laju transisi dari populasi node yang laten menjadi populasi node yang terinfeksi worm. Selain itu, laju populasi ini berkurang karena adanya laju transisi dari populasi node laten menjadi populasi node yang pulih dan berkurang karena kerusakan alami pada populasi node yang laten.

Persamaan (1c) menyatakan laju perubahan populasi node yang terinfeksi worm terhadap waktu. Laju populasi ini bertambah karena adanya laju transisi dari populasi node laten menjadi populasi node yang terinfeksi worm, sedangkan berkurang karena adanya kerusakan alami pada populasi node yang terinfeksi worm, kemudian berkurang karena adanya laju transisi dari populasi node yang terinfeksi worm menjadi populasi node yang dikarantina dan berkurang karena adanya laju transisi dari populasi node yang terinfeksi worm menjadi populasi node yang pulih. Persamaan (1d) menyatakan laju perubahan populasi node yang dikarantina terhadap 
waktu. Laju populasi ini bertambah karena adanya laju transisi dari populasi node yang terinfeksi worm menjadi populasi node yang dikarantina, sedangkan berkurang karena adanya laju transisi dari populasi node yang dikarantina menjadi populasi node yang pulih dan berkurang karena adanya kerusakan alami pada node yang dikarantina. Persamaan (1e) menyatakan laju perubahan populasi node yang pulih terhadap waktu. Laju populasi ini bertambah karena adanya laju transisi dari populasi node yang laten menjadi populasi node yang pulih, kemudian bertambah karena adanya laju transisi dari populasi node yang terinfeksi worm menjadi populasi node yang pulih, bertambah karena adanya laju transisi dari populasi node terinfeksi worm yang dikarantina menjadi populasi node yang pulih dan berkurang karena adanya kerusakan alami pada populasi node yang pulih.

\subsection{Turunan Fraksional}

\subsubsection{Pengertian Turunan Fraksional}

Pendekatan turunan fraksional yang digunakan dalam penelitian ini adalah turunan fraksional Caputo. Keuntungan menggunakan turunan fraksional Caputo adalah nilai awal pada persamaan diferensial orde fraksional dengan turunan Caputo dalam bentuk orde integer yang memiliki kesamaan bentuk dengan persamaan diferensial orde integer [7].

Definisi 1[7] Misalkan $\alpha>0, t>0$ dan $n \in \mathbb{N}$. Turunan fraksional Caputo $D^{\alpha}:=\frac{d^{\alpha}}{d t^{\alpha}}$, dengan order fraksional $\alpha$, untuk fungsi $f(t)$ didefinisikan sebagai:

$$
D^{\alpha} f(t)=I^{n-\alpha} D^{n} f(t)=\left\{\begin{array}{lc}
\frac{1}{\Gamma(n-\alpha)} \int_{0}^{t} \frac{f^{(n)}(s)}{(t-s)^{\alpha-n+1}} d s, & n-1<\alpha<n \\
f^{(n)}(t) & ,
\end{array} .\right.
$$

dengan $\Gamma(\cdot)$ adalah fungsi gamma. Pada penelitian ini diasmsikan nilai $\alpha \in(0,1]$.

\subsubsection{Kestabilan Lokal Titik Setimbang SPDF}

Titik setimbang adalah suatu kondisi ketika laju perubahan suatu subpopulasi tertentu sepanjang waktu adalah nol. Analisis kestabilan dilakukan dengan menggunakan pendekatan nilai eigen sehingga sifat kestabilan yang diperoleh merupakan kestabilan lokal.

Teorema 2[8] Misalkan $D^{\alpha} x(t)=f(x), 0<\alpha \leq 1$, dan $x \in \mathbb{R}^{n}, \boldsymbol{f} \in \mathbb{R}^{n}$ merupakan SPDF non linier. Titik setimbang $x^{*}$ merupakan solusi dari $f(x)=0$. Titik setimbang $x^{*}$ stabil asimtotis lokal jika untuk semua nilai eigen $\lambda_{j}(j=1,2, \ldots, n)$ dari matriks Jacobian $A=\frac{\partial f}{\partial x}$ yang dievaluasi di titik setimbang $x^{*}$ memenuhi $\left|\arg \lambda_{j}\right|>\frac{\alpha \pi}{2}$.

\subsubsection{Basic reproduction number $\left(R_{0}\right)$}


Basic reproduction number $\left(R_{0}\right)$ merupakan kuantitas penting dalam kasus infeksi epidemiologi penyakit. Basic reproduction number $R_{0}$ didefinisikan sebagai rata-rata jumlah infeksi sekunder yang disebabkan oleh infeksi primer tunggal pada populasi susceptible. Dalam penelitian ini, metode yang digunakan untuk menentukan $R_{0}$ adalah metode Next Generation Matrix (NGM) yang dikembangkan oleh Driessche dan Watmough [9].

\subsubsection{Analisis Sensitivitas}

Analisis sensitivitas parameter dilakukan untuk mengetahui parameter apa saja pada model yang memiliki pengaruh besar terhadap laju perubahan model. Analisis sensitivitas parameter dilakukan dengan menghitung nilai indeks sensitivitas dari parameter tersebut. Indeks sensitivitas dari Basic reproduction number $R_{0}$ adalah $\frac{\partial R_{0}}{\partial m} \frac{m}{R_{0}}$ dengan $m$ adalah parameter yang akan dianalisis [10].

\subsubsection{Simulasi Numerik}

Simulasi numeric dilakukan dengan menggunakan MATLAB R2009a.

\section{Hasil dan Pembahasan}

\subsection{Formulasi Model}

Sebagaimana yang dilakukan oleh Das dan Gupta [5] dan Angstmann dkk [6], model matematika penyebaran worm berbasis Wi-Fi pada smartphone yang yang disajikan pada (1a) (1e) dapat diperumum menjadi SPDF dengan cara mengubah turunan pertama pada SPDB menjadi turunan berorde $\alpha$ dengan $\alpha \in(0,1]$. Model matematika orde fraksional penyebaran worm berbasis Wi-Fi pada smartphone sebagai berikut:

$$
\begin{aligned}
& \frac{d^{\alpha} S}{d t^{\alpha}}=-\beta S I+\mu N-\mu S \\
& \frac{d^{\alpha} E}{d t^{\alpha}}=\beta S I-\eta E-\varepsilon E-\mu E \\
& \frac{d^{\alpha} I}{d t^{\alpha}}=\eta E-\mu I-\xi I-\gamma I \\
& \frac{d^{\alpha} Q}{d t^{\alpha}}=\xi I-\varphi Q-\mu Q \\
& \frac{d^{\alpha} R}{d t^{\alpha}}=\varepsilon E+\gamma I+\varphi Q-\mu R
\end{aligned}
$$

dengan $\mu, \beta, \varphi, \gamma, \varepsilon, \eta, \xi>0$ dan $0<\alpha \leq 1$

\subsection{Analisis Kestabilan Titik Setimbang}

\subsubsection{Titik Setimbang}

Berdasarkan Teorema 1, titik setimbang pada model matematika orde fraksional penyebaran worm berbasis Wi-Fi pada smartphone merupakan solusi dari system persamaan non linear: 


$$
\begin{aligned}
& -\beta S I+\mu N-\mu S=0 \\
& \beta S I-\eta E-\varepsilon E-\mu E=0 \\
& \eta E-\mu I-\xi I-\gamma I=0 \\
& \xi I-\varphi Q-\mu Q=0 \\
& \varepsilon E+\gamma I+\varphi Q-\mu R=0
\end{aligned}
$$

Titik setimbang bebas worm $P_{0}$ merupakan suatu kondisi ketika tidak terjadi penyebaran worm. Kondisi ini terjadi ketika tidak ada node yang terinfeksi worm $(E=I=0)$ sehingga mengakibatkan tidak ada node yang dikarantina. Oleh karena itu, dengan mensubtitusikan $E=$ $I=0$ ke dalam persamaan (4a)-(4b) diperoleh titik setimbang bebas worm $P_{0}=$ $\left(S_{0}, E_{0}, I_{0}, Q_{0}, R_{0}\right)=(N, 0,0,0,0)$, dengan $N$ merupakan jumlah keseluruhan populasi node dalam sistem.

Titik setimbang endemik $P_{1}$ merupakan suatu kondisi ketika terjadi penyebaran worm pada smartphone dengan cara menginfeksi jaringan Wi-Fi yang sedang terhubung dengan smartphone tersebut. Kondisi tersebut terjadi ketika $I \neq 0$. Berdasarkan perhitungan diperoleh titik setimbang $P_{1}=\left(S^{*}, E^{*}, I^{*}, Q^{*}, R^{*}\right)=\left(\frac{(\eta+\varepsilon+\mu)(\xi+\gamma+\mu)}{\eta \beta}, \frac{\mu\left(N-S^{*}\right)}{\eta+\varepsilon+\mu}, \frac{\mu\left(N-S^{*}\right)}{\beta S^{*}}, \frac{\xi I^{*}}{\varphi+\mu}, \frac{\varepsilon E^{*}+\gamma I^{*}+\varphi Q^{*}}{\mu}\right)$. Titik setimbang endemik eksis karena $N \geq S^{*}$.

\subsubsection{Analisis Kestabilan}

Pada subbab in dikaji tentang kestabilan titik setimbang model (3a)-(3e) di atas dengan terlebih dahulu menghitung basic reproduction number $R_{0}$. Langkah pertama menentukan $R_{0}$ dengan menggunakan metode NGM [9] adalah dengan mengambil nilai $\alpha=1$ dan menentukan matriks $X$ dengan elemenya terdiri dari populasi yang terinfeksi dalam model. Populasi ini merupakan populasi yang dapat menularkan maupun populasi yang tidak dapat menularkan penyakit kepada populasi lain. Oleh karena itu, $X=\left(\begin{array}{c}E \\ I\end{array}\right)$. Selanjutnya matriks $\frac{d X}{d t}$ didekomposisi kedalam bentuk $\frac{d X}{d t}=F(X)-Z(X)$ dengan $F(X)$ menyatakan matriks transmisi dan $Z(X)$ menyatakan matriks transisi. Matriks transmisi $F(X)$ adalah matriks yang elemennya memuat interaksi antara populasi $S$ dengan populasi $I$ dari matriks $\dot{X}$.Sedangkan elemen matriks X yang tidak termasuk kedalam $F(X)$ menjadi elemen matriks $Z(X)$. Hasil dekomposisi tersebut adalah $\frac{d X}{d t}=\left(\begin{array}{c}\frac{d E}{d t} \\ \frac{d I}{d t}\end{array}\right)=\left(\begin{array}{c}\beta S I-\eta E-\varepsilon E-\mu E \\ \eta E-\mu I-\xi I-\gamma I\end{array}\right)=\left(\begin{array}{c}\beta S I \\ 0\end{array}\right)-\left(\begin{array}{c}\eta E+\varepsilon E+\mu E \\ -\eta E+\mu I+\xi I+\gamma I\end{array}\right)=F(X)-Z(X)$.

Oleh karena itu $F(X)=\left(\begin{array}{c}\beta S I \\ 0\end{array}\right)$ dan $Z(X)=\left(\begin{array}{c}\eta E+\varepsilon E+\mu E \\ -\eta E+\mu I+\xi I+\gamma I\end{array}\right)$. Matriks Jacobian dari matriks $F$ dan $Z$ terhadap $X$ di titik setimbang bebas worm $P_{0}=(N, 0,0,0,0)$ berturut-turut 
adalah $\mathbb{F}=\left(\begin{array}{cc}0 & \beta N \\ 0 & 0\end{array}\right)$ dan $\mathbb{Z}=\left(\begin{array}{cc}\eta+\varepsilon+\mu & 0 \\ -\eta & \mu+\xi+\gamma\end{array}\right) . \quad$ Berdasarkan hasil ini diperoleh $\mathbb{F Z}^{-1}=\left(\begin{array}{cc}\frac{\beta \eta N}{(\eta+\varepsilon+\mu)(\mu+\xi+\gamma)} & \frac{\beta N}{\mu+\xi+\gamma} \\ 0 & 0\end{array}\right) . \quad$ Nilai eigen matriks $\mathbb{F Z}^{-1}$ adalah $\lambda_{1}=\frac{\beta \eta N}{(\eta+\varepsilon+\mu)(\mu+\xi+\gamma)}$ dan $\lambda_{2}=0$. Oleh karena itu, $\mathcal{R}_{0}=\max \left\{|\lambda|: \lambda\right.$ nilai eige $\mathrm{n}$ dari $\left.\mathrm{FZ}^{-1}\right\}=\frac{\beta \eta N}{a b}$ dengan $a=\eta+\varepsilon+$ $\mu$ dan $b=\mu+\xi+\gamma$.

Teorema kestabilan titik setimbang bebas worm model orde fraksional (3a) - (3e) diberikan dalam teorema berikut.

Teorema 3. Titik setimbang bebas worm $P_{0}$ pada model (3a) - (3e) stabil asimtotis lokal untuk setiap $\alpha \in(0,1]$ jika dan hanya jika $R_{0}<1$.

Bukti : Matriks Jacobian model (3a) - (3e) di sekitar titik setimbang bebas worm $P_{0}$ adalah

$$
A\left(P_{0}\right)=\left(\begin{array}{ccccc}
-\mu & 0 & -\beta N & 0 & 0 \\
0 & -(\eta+\varepsilon+\mu) & \beta N & 0 & 0 \\
0 & \eta & -(\mu+\xi+\gamma) & 0 & 0 \\
0 & 0 & \xi & -(\varphi+\mu) & 0 \\
0 & \varepsilon & \gamma & 0 & -\mu
\end{array}\right)
$$

Nilai eigen dari matriks $A\left(P_{0}\right)$ merupakan akar persamaan karakteristik

$$
(\lambda+\mu)^{2}(\lambda+\varphi+\mu)\left[\lambda^{2}+(a+b) \lambda+a b-\eta \beta N\right]=0
$$

yang diperoleh dari $\operatorname{det}\left(\lambda I-A\left(P_{0}\right)\right)=0$ [11] dengan $a=\eta+\varepsilon+\mu \operatorname{dan} b=\mu+\xi+\gamma$.

Berdasarkan persamaan (5) diperoleh bahwa nilai eigen dari matriks $A\left(P_{0}\right)$ adalah $\lambda_{1}=$ $\lambda_{2}=-\mu, \lambda_{3}=-\varphi-\mu$, dan dua akar lain yang merupakan akar-akar dari persamaan polinomial:

$$
\lambda^{2}+m_{1} \lambda+m_{2}=0
$$

dengan $m_{1}=a+b, m_{2}=a b-\eta \beta N$.

Karena parameter $\mu$ dan $\varphi$ diasumsikan bernilai positif, maka untuk setiap $j=1,2,3, \lambda_{j}<$ 0 , sehingga untuk setiap $\alpha \in(0,1],\left|\arg \left(\lambda_{j}\right)\right|=\pi>\frac{\alpha \pi}{2}, j=1,2,3$. Karena $m_{1}>0$, maka persamaan (6) tidak mempunyai akar kompleks dengan bagian real positif. Oleh karena itu untuk menentukan akar persamaan (6) yang memenuhi kriteria kestabilan titik setimbang pada SPDF cukup dengan menggunakan kriteria Routh-Hurwitz (Proposition 1 (ii) dalam [12]), yaitu $m_{1}, m_{2}>0$. Karena syarat $m_{1}>0$ telah terpenuhi, maka syarat kestabilannya tinggal $m_{2}>0$, yaitu $a b-\eta \beta N>0$ atau $R_{0}=\frac{\eta \beta N}{a b}<1$. Berdasarkan uraian di atas diperoleh bahwa untuk setiap $\alpha \in(0,1],\left|\arg \left(\lambda_{i}\right)\right|=\pi>\frac{\alpha \pi}{2}, i=4,5$ jika dan hanya jika $R_{0}<1$. 
Selanjutnya diberikan teorema kestabilan titik endemik model orde fraksional (3a) - (3e) sebagai berikut.

\section{Teorema 4 Titik setimbang endemik}

$$
P_{1}=\left(\frac{(\eta+\varepsilon+\mu)(\xi+\gamma+\mu)}{\eta \beta}, \frac{\mu\left(N-S^{*}\right)}{\eta+\varepsilon+\mu}, \frac{\mu\left(N-S^{*}\right)}{\beta S^{*}}, \frac{\xi I^{*}}{\varphi+\mu}, \frac{\varepsilon E^{*}+\gamma I^{*}+\varphi Q^{*}}{\mu}\right)
$$

pada model (3a)-(3e) stabil asimtotis lokal untuk setiap $\alpha \in(0,1]$ jika dan hanya jika $R_{0}>1$.

Bukti : Matriks Jacobian model (3a) - (3e) di sekitar titik setimbang bebas worm $P_{1}$ adalah

$$
A\left(P_{1}\right)=\left(\begin{array}{ccccc}
-\beta I^{*}-\mu & 0 & -\beta S^{*} & 0 & 0 \\
\beta I^{*} & -(\eta+\varepsilon+\mu) & \beta S^{*} & 0 & 0 \\
0 & \eta & -(\mu+\xi+\gamma) & 0 & 0 \\
0 & 0 & \xi & -(\varphi+\mu) & 0 \\
0 & \varepsilon & \gamma & 0 & -\mu
\end{array}\right)
$$

Nilai eigen dari matriks $A\left(P_{1}\right)$ merupakan akar persamaan karakteristik

$$
(\lambda+\mu)(\lambda+\varphi+\mu)\left[\lambda^{3}+(a+b+c) \lambda^{2}+\left(a b+b c+c a-\eta \beta S^{*}\right) \lambda+a b c-\mu \eta \beta S^{*}\right]=0
$$

dengan $a=\eta+\varepsilon+\mu, b=\mu+\xi+\gamma$ dan $c=\beta I^{*}+\mu$.

Berdasarkan persamaan (7) diperoleh nilai eigen dari matriks $A\left(P_{1}\right)$ adalah $\lambda_{1}=-\mu, \lambda_{2}=$ $-\varphi-\mu$, dan tiga akar yang lain merupakan akar-akar dari persamaan berikut:

$$
\lambda^{3}+m_{1} \lambda^{2}+m_{2} \lambda+m_{3}=0
$$

dengan $m_{1}=a+b+c, m_{2}=a b+b c+c a-\eta \beta S^{*}$ dan $m_{3}=a b c-\mu \eta \beta S^{*}$.

Karena parameter $\mu$ dan $\varphi$ diasumsikan bernilai positif, maka $\lambda_{1}, \lambda_{2}<0$, sehingga untuk setiap $\alpha \in(0,1]\left|\arg \left(\lambda_{i}\right)\right|=\pi>\frac{\alpha \pi}{2}, i=1,2$. Selanjunya, misalkan $\lambda_{i}, i=3,4,5$ merupakan akar dari (8). Berdasarkan Proposition 1 (vi) dalam [12], jika $\left|\arg \lambda_{j}\right|>\frac{\alpha \pi}{2}, j=3,4,5$, maka $m_{3}>0$. Karena

$$
\begin{aligned}
m_{3} & =a b c-\mu \eta \beta S^{*} \\
& =(\eta+\varepsilon+\mu)(\mu+\xi+\gamma)\left(\frac{\mu\left(N-\frac{(\eta+\varepsilon+\mu)(\xi+\gamma+\mu)}{\eta \beta}\right)}{\frac{(\eta+\varepsilon+\mu)(\xi+\gamma+\mu)}{\eta \beta}}+1\right)-\mu(\eta+\varepsilon+\mu)(\xi+\gamma+\mu) \\
& =(\eta+\varepsilon+\mu)(\mu+\xi+\gamma) \mu \frac{\eta \beta N}{(\eta+\varepsilon+\mu)(\xi+\gamma+\mu)}-\mu(\eta+\varepsilon+\mu)(\xi+\gamma+\mu) \\
& =(\eta+\varepsilon+\mu)(\mu+\xi+\gamma) \mu\left(R_{0}-1\right)=a b \mu\left(R_{0}-1\right)>0 .
\end{aligned}
$$

maka $R_{0}>1$. Sebaliknya misalkan $R_{0}>1$. Karena

$$
\begin{aligned}
m_{1} m_{2} & -m_{3}=(a+b+c)\left(a b+b c+c a-\eta \beta S^{*}\right)-\left(a b c-\mu \eta \beta S^{*}\right) \\
& =(a+b+c)(a b+b c+c a-a b)-(a b c-\mu a b) \\
& =(a+b+c)(b c+c a)-a b c+\mu a b
\end{aligned}
$$




$$
=(a+b+c) c a+(b+c) b c+\mu a b>0 .
$$

Karena $m_{1}>0, m_{3}>0$, dan $m_{1} m_{2}-m_{3}>0$, maka $m_{2}>0$. Kondisi $m_{1}>0, m_{3}>$ $0, m_{3}>0$, dan $m_{1} m_{2}-m_{3}>0$ memenuhi kriteria Routh-Hurwitz ((Proposition 1 (iii) dalam [12]). Dengan demikian, jika $R_{0}>1$, maka titik setimbang $P_{1}$ stabil asimtotis lokal/.

\subsection{Analisis Sensitivitas}

Nilai parameter yang digunakan untuk perhitungan indeks sensitivitas merujuk pada Tabel 3 ketika $R_{0}>1$. Untuk bilangan $R_{0}=\frac{\eta \beta N}{a b}$ dengan $a=\eta+\varepsilon+\mu$ dan $b=\mu+\xi+\gamma$ terdapat enam parameter yang akan dicari indeks sensitivitasnya yaitu $\beta, \eta, \varepsilon, \mu, \xi$ dan $\gamma>0$. Nilai

Hasil analisis indeks sensitivitas parameter dari $R_{0}$ terhadap parameter pada model matematika orde fraksional penyebaran worm berbasis Wi-Fi pada smartphone diberikan pada Tabel 2 berikut.

Tabel 2 Indeks sensitivitas parameter

\begin{tabular}{ccc}
\hline Parameter & Nilai & Indeks Sensitivitas \\
\hline$\beta$ & 0.000006 & 1 \\
$\eta$ & 0.01 & 0,0006056 \\
$\varepsilon$ & 0.00003 & $-0,0000059$ \\
$\mu$ & 0.0000003 & $-0,0010280$ \\
$\xi$ & 0.06 & $-0,8656775$ \\
$\gamma$ & 0.03 & $-0,1427959$ \\
\hline
\end{tabular}

Berdasarkan Tabel 2 diperoleh bahwa

a. Indeks sensitivitas untuk $\beta$ adalah 1, artinya apabila laju kontak antara node rentan dengan node terinfeksi bertambah (berkurang) sebesar $10 \%$ akan mengakibatkan $R_{0}$ bertambah (berkurang) sebesar $10 \%$.

b. Indeks sensitivitas untuk $\eta$ adalah 0,0006056, artinya apabila laju transisi dari node laten menjadi node terinfeksi bertambah (berkurang) sebesar $10 \%$ akan mengakibatkan $R_{0}$ bertambah (berkurang) sebesar 0,006\%.

c. Indeks sensitivitas untuk $\varepsilon$ adalah $-0,0000059$, artinya apabila laju transisi dari node laten menjadi node node pulih bertambah (berkurang) sebesar $10 \%$ akan mengakibatkan $R_{0}$ berkurang (bertambah) sebesar 0,0000059\%.

d. Indeks sensitivitas untuk $\mu$ adalah -0,0010280, artinya apabila laju masuknya node baru dalam sistem dan laju kerusakan alami pada node bertambah (berkurang) sebesar $10 \%$ akan mengakibatkan $R_{0}$ berkurang (bertambah) sebesar $0,01 \%$. 
e. Indeks sensitivitas untuk $\xi$ adalah $-0,8656775$, artinya apabila laju masuknya node baru dalam sistem dan laju kerusakan alami pada node bertambah (berkurang) sebesar $10 \%$ akan mengakibatkan $R_{0}$ berkurang (bertambah) sebesar $8,7 \%$.

f. Indeks sensitivitas untuk $\gamma$ adalah $-0,1427959$, artinya apabila laju masuknya node baru dalam sistem dan laju kerusakan alami pada node bertambah (berkurang) sebesar $10 \%$ akan mengakibatkan $R_{0}$ berkurang (bertambah) sebesar $1,4 \%$.

Berdasarkan analisis sensitivitas parameter di atas diperoleh bahwa parameter pada model yang memiliki pengaruh besar terhadap laju perubahan model adalah $\beta$ dan $\xi$.

\subsection{Simulasi Numerik}

Pada bagian ini akan dilakukan simulasi numerik terhadap model matematika penyebaran worm berbasis Wi-Fi pada smartphone dengan menggunakan bantuan software MATLAB. Nilai parameter yang digunakan pada simulasi ini disajikan pada Tabel 3 berikut:

Tabel 3 Nilai parameter model matematika

\begin{tabular}{ccc}
\hline Parameter & Nilai & Sumber \\
\hline$\mu$ & 0.0000003 & {$[11]$} \\
$\beta$ & $\beta_{1}=0.0000005$ & {$[11]$} \\
$\varphi$ & $\beta_{2}=0.000006$ & Asumsi \\
& 0.05 & {$[11]$} \\
$\gamma$ & $\gamma_{1}=0.01$ & {$[11]$} \\
$\varepsilon$ & $\gamma_{2}=0.03$ & Asumsi \\
$\eta$ & 0.00003 & Asumsi \\
& $\eta_{1}=0.02$ & Asumsi \\
$\xi$ & $\eta_{2}=0.01$ & {$[11]$} \\
& $\xi_{1}=0.05$ & Asumsi \\
& $\xi_{2}=0.06$ &
\end{tabular}

\subsubsection{Simulasi Bebas Worm}

Pada simulasi bebas worm, nilai awal yang digunakan adalah $\left(S_{0}, E_{0}, I_{0}, Q_{0}, R_{0}\right)=$ $(99000,500,500,0,0)$. Berdasarkan nilai parameter pada Tabel 3 (untuk $\left.\beta=\beta_{1}, \gamma=\gamma_{1}, \eta=\eta_{1}, \xi=\xi_{1}\right)$ diperoleh $R_{0}=0.832<1$ yang menunjukkan bahwa titik setimbang bebas worm stabil asimtotis lokal. Simulasi dilakukan dengan mengambil nilai orde fraksional $\alpha=0,33,0,58,0,73,0.95$, dan 1 serta interval waktu selama 100 satuan waktu. 
Berikut hasil simulasi model matematika penyebaran worm berbasis Wi-Fi pada smartphone.
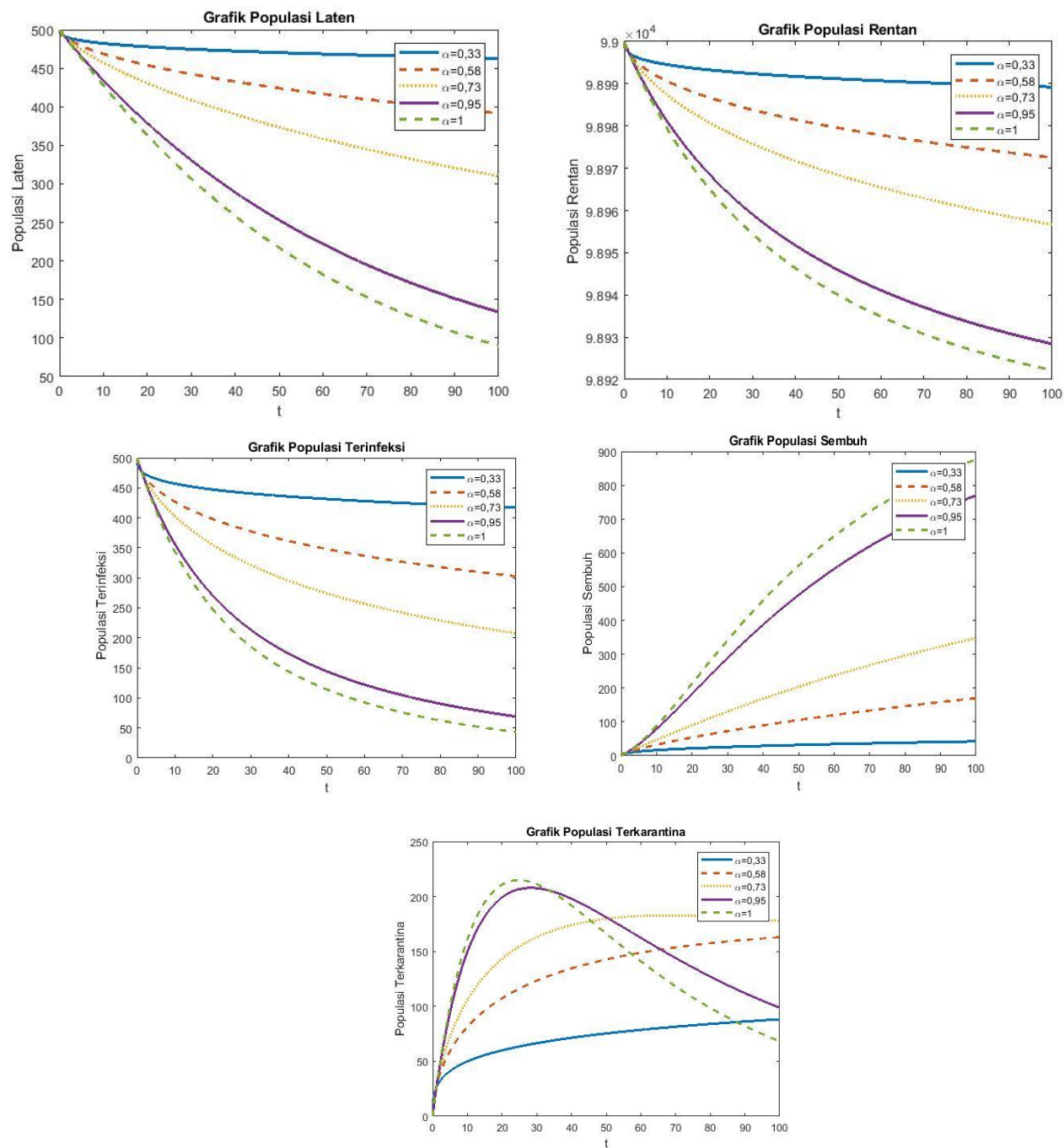

Gambar 2. Grafik dinamika perubahan populasi model matematika penyebaran worm berbasis Wi-Fi pada smartphone untuk $R_{0}<1$ dan nenerapa orde fraksional $\alpha$.

Berdasarkan Gambar 2 pada setiap $\alpha$ dapat dilihat bahwa populasi node rentan mengalami kenaikan, populasi node laten dan populasi node terinfeksi mengalami penurunan karena tidak adanya penyebaran worm pada jaringan Wi-Fi, sehingga populasi node yang dikarantina mengalami penurunan. Oleh karena tidak adanya penyebaran worm pada jaringan $\mathrm{Wi}$-Fi maka populasi node pulih mengalami kenaikan. Hal tersebut mengindikasikan kondisi bebas worm.

\subsubsection{Simulasi Kondisi Endemik}

Nilai awal yang digunakan pada simulasi kondisi endemik adalah $\left(S_{0}, E_{0}, I_{0}, Q_{0}, R_{0}\right)=$ $(99000,500,500,0,0)$. Berdasarkan nilai parameter Tabel 3 (untuk $\left.\beta=\beta_{2}, \gamma=\gamma_{2}, \eta=\eta_{2}, \xi=\xi_{2}\right)$ diperoleh $R_{0}=6.646>1$ yang menunjukkan bahwa titik setimbang endemik worm stabil asimtotis lokal. Simulasi dilakukan dengan mengambil nilai 
orde fraksional $\alpha=0,33,0,58,0,73,0.95$, dan 1 serta interval waktu selama 100 satuan waktu.

Berikut hasil simulasi model model matematika penyebaran worm berbasis Wi-Fi pada smartphone.
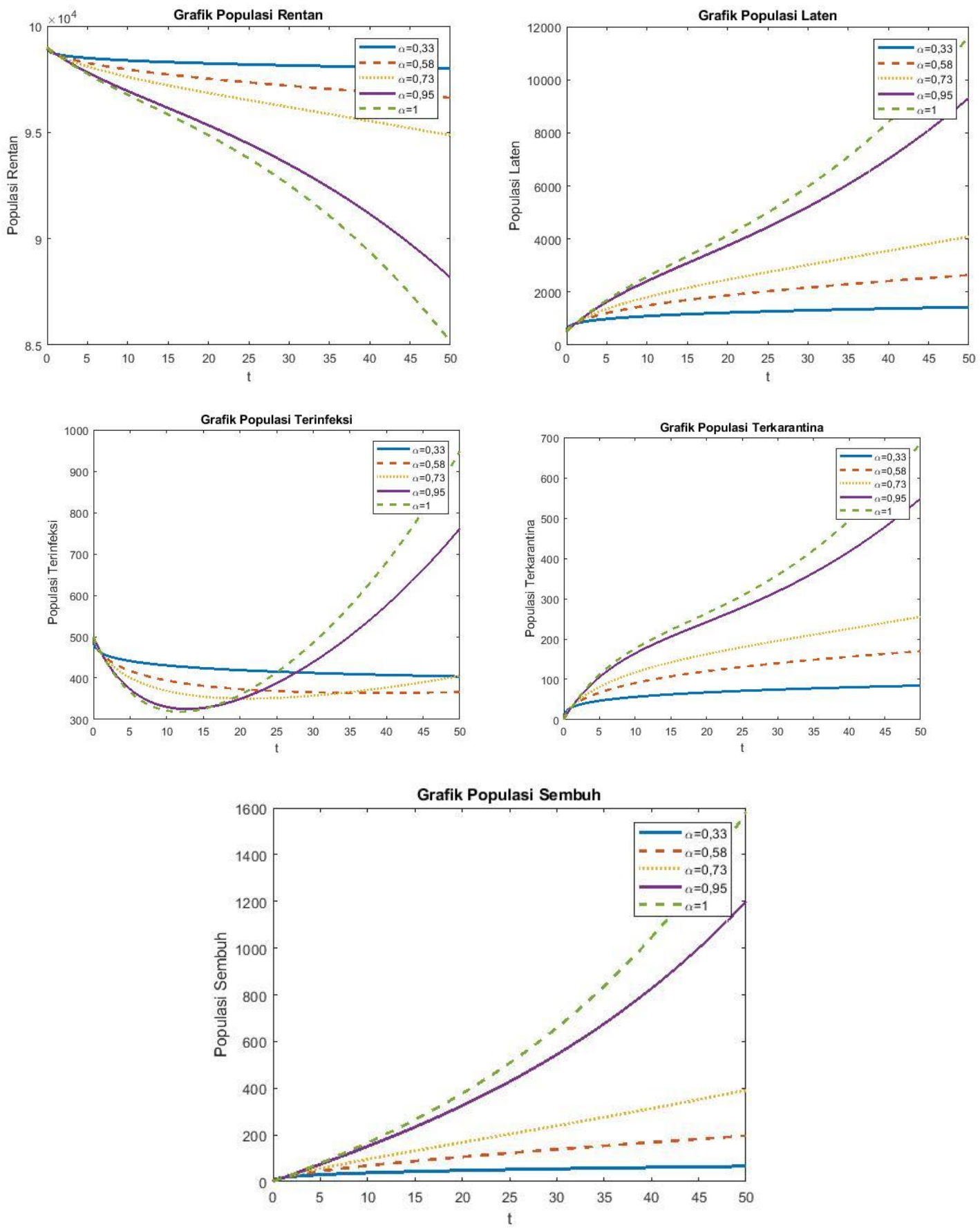

Gambar 3. Dinamika perubahan populasi model matematika penyebaran worm berbasis $\mathrm{Wi}$ Fi pada smartphone untuk $R_{0}>1$ dan beberapa orde fraksional $\alpha$ Berdasarkan Gambar 3 pada setiap $\alpha$ dapat dilihat bahwa populasi node rentan mengalami penurunan dari kondisi awal yang diberikan sedangkan populasi node laten, populasi 
node terinfeksi, populasi node yang di karantina mengalami kenaikan. Oleh karena populasi node laten dan populasi node terinfeksi akan di karantina oleh base station Wi-Fi, maka populasi node laten dan populasi node terinfeksi akan menjadi populasi node pulih. Akibatnya, populasi node pulih mengalami kenaikan. Hal tersebut mengindikasikan kondisi endemik atau adanya penyebaran worm.

Berdasakan Gambar 2 dan Gambar 3 di atas diperoleh bahwa jika otde $\alpha$ semakin besar, populasi akan mengalami kenaikan lebih cepat atau mengalami penurunan lebih lambat.

\section{Simpulan}

Berdasarkan simulasi numerik yang telah dilakukan, diperoleh bahwa pada kondisi bebas worm, yaitu $R_{0}<1$, populasi node rentan mengalami kenaikan, populasi node laten dan populasi node terinfeksi mengalami penurunan karena tidak adanya penyebaran worm pada jaringan Wi$F i$, sehingga populasi node yang dikarantina mengalami penurunan. Oleh karena tidak adanya penyebaran worm pada jaringan Wi-Fi maka populasi node pulih mengalami kenaikan. Hal terserbut mengindikasikan kondisi bebas worm. Di sisi lain, pada kondisi endemik, yaitu $R_{0}>$ 1, populasi node rentan mengalami penurunan dari kondisi awal yang diberikan sedangkan populasi node laten, populasi node terinfeksi, populasi node yang di karantina mengalami kenaikan. Oleh karena populasi node laten dan populasi node terinfeksi akan di karantina oleh base station Wi-Fi, maka populasi node laten dan populasi node terinfeksi akan menjadi populasi node pulih. Akibatnya, populasi node pulih mengalami kenaikan. Hal tersebut mengindikasikan kondisi endemik atau adanya penyebaran worm. Selain itu, dapat disimpulkan pula bahwa jika otde $\alpha$ semakin besar, populasi akan mengalami kenaikan lebih cepat atau mengalami penurunan lebih lambat.

\section{Daftar Pustaka}

[1] A. Sukmaaji and Rianto, Jaringan Komputer. Yogyakarta: Andi Publisher, 2008.

[2] Kominfo, "Kemkominfo: Indonesia Raksasa Digital Asia. Kementrian Komunikasi dan Informatika Republik Indonesia.”.

[3] Xiao X., Fu P., Dou C., Li Q., Hu G., and Xia S., "Design and analysis of SEIQR worm propagation model in mobile internet," J. Commun Nonlinear Sci Numer Simulat, vol. 43, pp. 341-350, 2017.

[4] Y. H. and C. G., "Network virus epidemic model with the point to group information propagation,” J. Appl. Math. Comput., vol. 206, pp. 357-67, 2008. 
[5] S. Das and P. K. Gupta, "A mathematical model on fractional Lotka-Volterra equations," J. Theor. Biol., vol. 277, pp. 1-6, 2011.

[6] C. N. Angstmann, H. B.I., and M. A.V., "A fractional-Order Infectivity SIR Model," Physica A, vol. 2016, pp. 86-93, 2016.

[7] S. Z. Rida and A. A. M. Arafa, "New Method for Solving Linear Fractional Differential Equations,” Int. J. Differ. Equations, vol. 2011, p. 814132, 2011.

[8] M.S. Tavazoei, "A necessary condition for double scroll attractor existence in fractionalorder systems," Phys. Lett. A, vol. 367, pp. 102-113, 2007.

[9] V. den Driessche and J. Watmough, "Reproduction numbers and sub-threshold endemic equilibria for compartmental models of disease transmission," Math. Biosci., vol. 180, pp. 29-48, 2002.

[10] C. N., H. J.M., and C. J.M., "Determining Important Parameters In the Spread of Malaria Through the Sensitivity Analysis of a Mathematical Model," Bull. Math. Biol., vol. 70, pp. 1272-1296, 2008.

[11] A. H. and R. C., Elementary Linear Algebra. United State: Wiley, 2014.

[12] A. E., E.-S. A. M.A., and E.-S. Hala A.A., "On some Routh-Hurwitz conditions for fractional order differential equations and their applications in Lorenz, Rössler, Chua and Chen systems," Phys. Lett. Sect. A Gen. At. Solid State Phys., vol. 358, no. 1, pp. 1-4, 2006. 